\title{
REVIEW OF THE ECONOMIC LEGISLATION IN MAY 2013'
}

\author{
I.Tolmacheva, Yu.Grunina
}

In May, the following amendments were introduced in the legislation: from September 2013 amendments to Cl.4 and Cl.5 of Section I of Part I and Article 1153 of Part III of the Civil Code of the Russian Federation will be in effect; the specifics of carrying out of labor activities by high-skilled experts-foreign nationals was updated; procedure for identification of a foreign national who has no valid document was specified and definition of "the state support of innovation activities" was provided.

\section{Federal Laws of the Russian Federation}

1. Federal Law No.100-FZ of May 7, 2013 on INTRODUCTION OF AMENDMENTS INTO CL.4 AND CL.5 OF SECTION I OF PART I AND ARTICLE 1153 OF PART III OF THE CIVIL CODE OF THE RUSSIAN FEDERATION

Numerous amendments were introduced as regards transactions, including grounds and consequences of invalidity thereof, limitation periods and rules of calculation thereof and meetings in respect of which the law relates civil and legal consequences for all the persons who have the right to participate in such a meeting, as well as other persons.

In particular, new Article 157.1 "Consent on the Deal" was introduced. If for the deal to be carried out by virtue of the law a consent of the third person, a legal entity or a public authority or a local authority is required, the third person or a respective authority will inform of its consent or refusal the person who requested such a consent or other interested party within a reasonable period after receipt of the request of the person who requested the consent. In the preliminary consent on the deal, the subject of the deal to which the consent is given is to be determined. In case of further consent (approval) the deal to which the consent was given is to be specified. It is pointed out that silence is not regarded as consent on the deal, except for cases provided for by the law.

New Article 165.1 "Legally Important Messages" was introduced: statements, notifications, notices, requests or other legally important messages to which the law or deal relate civil and legal consequences for another person imply for that person the above consequences from the day of delivery of the respective message to that person or his/her representative. The message is deemed delivered also in cases if it was delivered to the person whom it was sent to (the addressee), but due to circumstances depending on that person it was not served, nor did the addressee got acquainted with it. Those rules are applied unless otherwise is provided for by the law or the terms of the deal, nor result from the rule or practice adopted in the relationship between the parties. Actually, it means that if any legally important messages were sent to the addressee, but for reasons which depended on the addressee they were not served, nor did the addressee get acquainted with them the message is deemed delivered.

Significant amendments were introduced in Cl.2 on invalidity of deals. So, a deal carried out with violation of the law is now recognized as voidable (reasons for voidability of the deal are specified in full in the Civil Code) rather than void. The deal may be recognized as void provided that the following three conditions are simultaneously in place: the deal does not violate the requirements of the law or other statutory act and at the same time infringes upon public interests or rights and law-protected interests of the third parties and in addition to that there is no reference in the law to the fact that such a deal is voidable and other consequences of violation which are not related to invalidity of the deal should be applied.

The period of limitation as regards claims for application of consequences of invalidity of the void deal and recognition of such a deal as invalid amounts to three years. It is to be noted that the legislator introduced an important detail that the period of limitation as regards the above claims begins from the day of fulfillment of the void deal while in case of filing of a suit by the person which is not a

1 The review was prepared with assistance of the KonsultantPlus legal system. 
party to the deal, from the day that person learnt or was to learn about the beginning of fulfillment of the deal. It is to be noted that the period of limitation for the person which is not a party to the deal must in no case exceed ten years from the day of beginning of fulfillment of the deal.

New Chapter 9.1. "Resolutions of Meetings" was introduced; now the norms of the above Chapter are applied by default to any general meetings such as: decisions of collegial governing bodies of a legal entity; decisions of meetings of creditors in case of bankruptcy and other.

So, a resolution of a meeting to which the law relates civil and legal consequences gives rise to legal consequences which the resolution of the meeting is aimed at for all the persons who had the right to participate in that meeting (participants in a legal entity, owners and creditors in case of bankruptcy and other participants in the civil and legal community), as well as other persons if it was established by the law or results from the subject of the relations. Resolution of the meeting is deemed approved if a majority of participants voted for it and it is to be noted that at least fifty percent of the total number of participants in the respective civil and legal community took part in that meeting. Resolution of a meeting can be passed by absentee voting. Common rules of taking of minutes are envisaged.

An important amendment was introduced into Article 186 as regards power of attorney; limitation of the power of attorney's maximum period of validity of three years has been eliminated. Now, it is determined that if the period of validity is not specified in the power of attorney it remains in force within a year from the day of execution thereof.

It is worth mentioning introduction of new Article 188.1 "Irrevocable Power of Attorney" which is issued for the purpose of fulfillment or securing of fulfillment of obligation to a representative or persons on whose behalf or in whose interests the representative acts. If such an obligation is related to fulfillment of entrepreneurial activities, the principal may specify in the power of attorney issued to the representative that that power of attorney cannot be revoked before the expiry date or it can be revoked only in cases provided for in the power of attorney. In any case, such a power of attorney can be revoked after termination of the obligation for which fulfillment or securing of fulfillment it was issued, as well as any time in case of abuse of power by the representative and in case of emergence of circumstances which explicitly point to the fact that such an abuse can take place. An irrevocable power of attorney should be notary certified.

The amendments will become effective from September 1, 2013, except for individual provisions in respect of which another effective date is set.

2. Federal Law No. 82-FZ of May 7, 2013 on INTRODUCTION OF AMENDMENTS IN THE FEDERAL LAW ON THE LEGAL STATUS OF FOREIGN NATIONALS IN THE RUSSIAN FEDERATION

It is established that the employer or customer of jobs (services) is not in a position to hire foreign nationals as high-skilled experts for commercial client service in retail trade in consumer goods (including pharmaceutical goods) irrespective of the assortment of salable goods, sales premises and forms of client service, except for workers who carry out management and coordination of activities related to trade. The list of professions (job positions and qualifications) of workers who carry out management and coordination of activities related to trade and qualification requirements to such workers are approved by federal executive authorities which carry out functions related to development and implementation of the state policy and statutory regulation in the sphere of employment and unemployment.

By resolutions of the Government of the Russian Federation, limitations were earlier introduced on hiring of foreign nationals as high skilled experts for work in the Russian Federation in customer service of retail trade in consumer goods (including pharmaceutical goods) irrespective of assortment of salable goods, sales premises and forms of customer service.

3. Federal Law no. 8-FZ of May 7, 2013 on INTRODUCTION OF AMENDMENTS INTO THE FEDERAL LAW ON THE LEGAL STATUS OF FOREIGN NATIONALS IN THE RUSSIAN FEDERATION

Other amendments introduced in the Law deal with identification of a foreign national who stays illegally in the territory of the Russian Federation and has no valid identification document. 
Identification of a foreign national is carried out on the basis of a decision of the head of the federal executive authority in the sphere of migration or its territorial unit. In the identification statement, a foreign national specifies his/her personal data (second name, first name, patronymic name and the date and place of birth), as well as the purpose, circumstances and the date of arrival in the Russian Federation.

For the purpose of identification of a foreign national, a territorial unit of the federal executive authority in the sphere of migration has the right, in particular, to:

- request submission from a foreign national of the information in writing required for identification of that person;

- carry out relevant checks, interview persons specified by a foreign national as witnesses at the place of residence or the place of stay of a foreign national, as well as carry out identification on the basis of a report of witness;

- use fingerprint information received in carrying out of the state fingerprint registration.

If on the basis of checks, interviews of witnesses and identification the authenticity of the personal data stated by the foreign national is proved, a territorial unit of the federal executive authority in the sphere of migration prepares a conclusion on the identification of the foreign national. A copy of the conclusion on the identification of the foreign national prepared by the territorial unit of the federal executive authority in the sphere of migration is handed over to the foreign national at his/her request.

The period of identification of a foreign national should not exceed three months.

4. Federal Law No. 93-FZ of May 7, 2013 on INTRODUCTION OF AMENDMENTS INTO ARTICLE 16.1 OF FEDERAL LAW ON SCIENCE AND STATE R\&D POLICY

The definition of "the state support of innovation activities" has been provided.

The state support of innovation activities includes a collection of measures taken by public authorities of the Russian Federation in accordance with the legislation of the Russian Federation and legislation of constituent entities of the Russian Federation for the purpose of establishment of the required legal, economic and organizational conditions, as well as motivation for legal entities and individuals engaged in innovation activities. 